and mortality in England and Wales was not exclusive to heart disease mortality, an observation you allow only for Canada (again without reference). Their early observation that the association is not disease-specific has been explored further with recent data from England and Wales. ${ }^{5}$ Although observational studies, uncontrolled for other possibly confounding socioenvironmental variables, have shown association between water calcium concentrations and mortality (age at death from various causes), is there one that shows association between water calcium concentrations and age-adjusted proportional mortality from heart disease? Estimates of calcium intake show that the average British diet $(1.0 \mathrm{~g} /$ person/day) exceeds considerably that from a large consumption of hard water (about $250 \mathrm{mg} /$ person/day). ${ }^{6}$ Are public health practitioners to prescribe hard water to bath in or more milk to drink ?

ROBERT R WEST

Welsh National School of Medicine,

Department of Community Medicine,

Departiff

'Heyden, S, Fournal of Chronic Diseases, 1976, 29, 149. 2 Allwright, S P A, et al, Lancet, 1974, 2, 860

Comstock, G W, American fournal of Epidemiology, 1971, 94, 1

Morris, J N, Crawford

West, R R, British fourn

Ministry of Agriculture, Fisheries and Food, Annua

Report of the National Food Survey, 1972. London, HMSO, 1974.

\section{Vitamin A and Sir Douglas Mawson}

SIR,-The article by Professor D J C Shearman on Sir Douglas Mawson (4 February, p 283) makes fascinating reading. There are, however, several points which I am not happy about.

The symptoms of the supposed hypervitaminosis A are not very convincing. Septic skin lesions are not uncommon in even healthy men in the Antarctic; for example, Ninnis had a whitlow a few days before his fatal fall into the crevasse. Sleep disturbances are common. Mawson complained of nervous symptoms and wrote that "I may go off my rocker very soon," but his wireless operator at base, who certainly never ate a dog's liver, became mentally unbalanced and had to be watched the whole time. Loss of skin occurs in frostbite and oedema occurs in starvation, and Mawson and Mertz were certainly very cold and very hungry. To say that Mawson lived because he might have given Mertz the more tasty livers is really guesswork; I suspect that Mawson lived because he just would not lie down and die.

One should think of other men in dire straits on other polar expeditions. For example, Nansen and Johansen in the Arctic Expedition of 1893-6 lived for months on an entirely protein diet of bear, seal, and walrus, and I do not think they threw away the livers. They never starved and they remained fit. Amundsen reached the South Pole by planning a diet of dog meat, including the livers, and his party returned to base in good shape, while Scott, who never ate a dog, died of starvation in his tent. My own favourite breakfast while a base in $75^{\circ}$ south latitude was fried Weddell seal liver with bacon, fried bread, and tinned tomatoes, and I certainly did not suffer.

In the chapter on Arctic survival in the Admiralty publication The Mariner's Handbook there is a warning not to eat the livers of polar bears and sealions because of their high vitamin A content, but there is also a warning not to try to exist on a diet of rabbit as one would die in a few weeks. I do not understand this, especially as my biologist friends tell me that there are no rabbits in the Arctic.

Wareham, Dorset

Christopher T BROWN

\section{Prolonged malaria prophylaxis}

SIR,-The recent correspondence (12 November, p 1287, and 17 December, p 1604) on malaria prophylaxis and on the side effects of chloroquine brought the letter from $\mathrm{Dr} \mathrm{K} \mathrm{O}$ Bentsi-Enchill (21 January, p 173), which calls for an answer.

Since the first observation by Hobbs and Calnan ${ }^{1}$ in 1958 of the adverse effects on the eye of long-term administration of chloroquine the great majority of cases reported refer to patients who were taking chloroquine for months and years at a daily dosage of 250-750 $\mathrm{mg}$ of salt (corresponding to about $150-500 \mathrm{mg}$ of the base) for rheumatoid arthritis, systemic lupus erythematosus, and other collagen disorders. Retrospective clinical and experimental reports, particularly numerous between 1963 and $1968,{ }^{2-5}$ confirmed that chloroquine retinopathy exists as a side effect of long-term treatment with this compound.

According to Mackenzie ${ }^{6}$ the risk of toxic retinal damage is negligible if the daily dose of chloroquine phosphate does not exceed $4 \mathrm{mg} /$ $\mathrm{kg}$ body weight daily. Since 1941 chloroquine at a dosage of $300 \mathrm{mg}$ base a week has been adopted in many parts of the world as one of the best protective antimalarial regimens, with the exception of those areas where resistance of Plasmodium falciparum to this compound exists. ${ }^{7}$ The French advocate chloroquine prophylaxis in malarious areas at a daily dosage of $100 \mathrm{mg}$, corresponding to $600-700$ $\mathrm{mg}$ base a week.

Over the past 20 years reports on the toxicity of chloroquine used as a malaria prophylactic have been remarkably few and usually connected with gross overdosage of the drug. When the observations linking chloroquine treatment of collagen diseases with adverse effects on vision became better known concern about any long-term use of this compound grew and influenced a number of statements, not always well founded.

Alman et $a l^{8}$ followed up 270 patients with rheumatoid arthritis whose annual intake of chloroquine averaged $70-75 \mathrm{~g}$ of the salt. The conclusion of this report was that "the risk of developing toxic retinal chloroquine damage seems to be small or absent even in long-term treatment, providing the dose is kept low." In this study the relevant "low" critical daily dose was $250 \mathrm{mg}$ of chloroquine salt (about $150 \mathrm{mg}$ base) for 10 months over a year, amounting to an annual intake of about 50-55 g of chloroquine base. The results of this study indicate that the usual dosage of chloroquine for prevention of malaria (300 $\mathrm{mg}$ base a week, corresponding to about $15 \mathrm{~g}$ per annum) is well within the generally safe limit for at leas 2-3 years. Even the higher "French" dosage of up to $700 \mathrm{mg}$ base a week may well be justified in highly malarious areas, though here the risk is greater.

The World Health Organisation ${ }^{9}$ advocates the maximum tolerable cumulative dosage of chloroquine as $100 \mathrm{~g}$ of base, corresponding to $2 \frac{1}{2}-3 \frac{1}{2}$ years of continuous prophylaxis (for an adult) depending on the relevant weekly dosage. These recommendations are well founded and may well be followed, although in individual cases age over 50, hypersensitivity, or other factors may justify some caution in the use of chloroquine and other 4-aminoquinolines for prevention of malaria.

I wish to thank Dr W Snellen for his help in providing the bibliographical data.

\section{J BRUCE-ChWATt}

Wellcome Museum of Medical

Science,

${ }^{1}$ Hobbs, H E, and Calnan, C D, Lancet, 1958, 1, 1207. 2 Nylander, U, Acta Ophthalmologica, 1967, 92, suppl fournal, 1968, 3,579 .

Gleiser, W, American fournal of Ophthalmology, 1969, 67, 399.

Lindquist, N G, Acta Pharmacologica, 1970, 28, suppl 1, p 64

Mackenzie, A, Arthritis and Rheumatology, 1970, 13, 280.

Alving, A S, et al, fournal of Clinical Investigation, $1948,27,60$

Elman, A, et al, Scandinavian fournal of Rheumatology, 1976, 5, 161.

or Records, 1976, No 24, pp 181-200.

\section{Delayed respiratory depression after use of fentanyl}

SIR,-As a user of moderately high doses of fentanyl I would like to add my comments to the report by Drs A P Adams and D A Pybus (4 February, $p$ 278). I fully endorse the views on premedication expressed by Drs C J Wright and $\mathrm{J} \mathrm{H}$ Williams (18 February, $\mathrm{p} 441$ ).

For over one year I have been using induction doses of fentanyl of $15-25 \mu \mathrm{g} / \mathrm{kg}$ (1.05$1.76 \mathrm{mg} / 70 \mathrm{~kg}$ ) with regular increments of $0 \cdot 25-0.5 \mathrm{mg}$ during major vascular surgery. Reversal of the neuromuscular blocking agent and withdrawal of nitrous oxide has been followed by rapid awakening and establishment of adequate respiration-a tidal volume frequently in excess of preoperative levels at a normal rate of $12-15 / \mathrm{min}$, a state which on clinical observation was maintained. Routine blood gas analysis approximately $45 \mathrm{~min}$ after reversal, however, revealed $\mathrm{PaCO}_{2}$ in the range $6.5-8.6 \mathrm{kPa}(49-65 \mathrm{~mm} \mathrm{Hg})$ in all the cases studied. The $\mathrm{PaO}_{2}$ varied between 15.0 and $54.0 \mathrm{kPa}$ (113 and $406 \mathrm{~mm} \mathrm{Hg}$ ). There was no cyanosis or hypoxia. Shivering, which increases carbon dioxide production, is an almost constant feature of prolonged surgery using this technique of analgesia. In the presence of an altered carbon dioxide response respiration is not automatically increased to compensate for increased production, thus resulting in elevated plasma levels. All the patients remained adequately oxygenated and none showed evidence of cardiovascular disturbance, presumably as the result of continuing attenuation of sympathoadrenergic activity by fentanyl. The hypercapnia is therefore probably of little clinical importance but certainly demands careful observation of patients anaesthetised in this manner.

Of much greater importance is premedication and postoperative analgesia in association with the intraoperative use of fentanyl. Morphine and related opiates used traditionally have, if given by intramuscular injection, a slow onset of action with a plateau effect lasting for 4-6 h and may therefore potentiate postoperative respiratory depression. All the patients described by Drs Adams and Pybus received opiate premedication. $\mathrm{Dr}$ 